\title{
Data Set on the Use of Continuous Improvement Programs in Companies From Open-Ended Questions
}

\author{
Amable Juarez-Tarraga ${ }^{1 *}$, Cristina Santandreu-Mascarell ${ }^{\text {1* }}$ and Juan A. Marin-Garcia ${ }^{2 *}$ \\ ${ }^{1}$ Departamento de Organización de Empresas, Universitat Politècnica de València, Valencia, Spain, ${ }^{2}$ ROGLE Departamento \\ de Organización de Empresas, Universitat Politècnica de València, Valencia, Spain
}

Keywords: perceptions, individual suggestions systems, permanent suggestions group systems, ad-hoc groups, semi-autonomous groups, continuous improvement, kaizen, data paper

OPEN ACCESS

Edited by:

Con Stough,

Swinburne University of

Technology, Australia

Reviewed by:

Vincenzo Cupelli,

Retired, Florence, Italy

Santiago Gascon,

University of Zaragoza, Spain

Michela Cortini,

University of Studies G. d'Annunzio

Chieti and Pescara, Italy

*Correspondence:

Amable Juarez-Tarraga

amjua@omp.upv.es

Cristina Santandreu-Mascarell

crisanma@omp.upv.es

Juan A. Marin-Garcia

jamarin@omp.upv.es

Specialty section:

This article was submitted to

Organizational Psychology,

a section of the journal

Frontiers in Psychology

Received: 11 April 2021

Accepted: 13 September 2021

Published: 13 October 2021

Citation:

Juarez-Tarraga $A$

Santandreu-Mascarell $C$ and Marin-Garcia JA (2021) Data Set on the Use of Continuous Improvement

Programs in Companies From

Open-Ended Questions.

Front. Psychol. 12:693727.

doi: 10.3389/fpsyg.2021.693727

\section{INTRODUCTION}

The current environment in which many industrial firms operate is characterized by intense competition with an increasingly predominant role of new technologies that develop toward smart factories, smart products and smart services embedded in an internet of things and services (Sandengen et al., 2016; Vinodh et al., 2021). In this context, the participation of workers and managers in continuous improvement programs can be a weapon for maintaining and improving competitiveness, making use of their knowledge and involvement, in order to enhancing the performance level of the entire organization (Terziovski and Sohal, 2000; Bessant et al., 2001; Van Dijk and Van Den Ende, 2002; García-Lorenzo and Prado, 2003; Wood, 2003; Lee et al., 2010; de Souza et al., 2018).

The great variety of tools, techniques, and classification criteria identified in the literature for applying participation of employees through continuous improvement practices in companies evidences its complexity (Bhuiyan and Baghel, 2005; Garcia-Sabater and Marin-Garcia, 2009; Marin-Garcia et al., 2012). For example, Lillrank et al. (2001) identified four dimensions in the design of tools in order to address the implementation of continuous improvement programs: if the activities are carried out by individuals or by groups; in the case of groups, if the groups are monofunctional or multifunctional and if they are comprised by members who are at the same level or if there are hierarchies within the group; if the activities are parallel or are integrated into the day to day life of the worker and, lastly, if the structure is permanent or is dismantled at the end of specific projects. And the Berger's (1997) classification mentions two dimensions: individual or group tasks and a parallel structure that is integrated into daily work.

These tools have been gradually introduced into companies and have been used in different ways, applying different indicators to assess their performance (Marin-Garcia, 2013; Juarez-Tarraga et al., 2016). For instance, the programs that first appeared in firms were suggestions systems., followed by quality circles and, later, improvement teams, with different configurations, were introduced (García-Lorenzo and Prado, 2003; Marin-Garcia et al., 2008).

Also, it is essential to point out that the level of use of these tools varies extensively in different working scenario depending on the organizational culture or country. According to EUROFOUND (2020) "Only one-fifth of European companies have found the secret for attaining optimal workplace well-being and business performance. 'High investment, high involvement' workplaces have been shown to offer the best outcomes for workers and employers, boosting performance and improving job quality through increasing employee autonomy, facilitating employee involvement and promoting training and learning" and according to the results of the latest survey on European 
Working Conditions Survey (EWCS) (EUROFOUND, 2016) significant differences at the country level are detected for the question "Are you involved in improving the work organization or work processes of the department or organization?".

Thus, despite their reputation and the benefits demonstrated in continuous improvement programmes, both economically (Appelbaum et al., 2000; Mathieu et al., 2008; Jaca-Garcia and Santos-Garcia, 2009; Subramony, 2009; Van Aken et al., 2010; Chalmers, 2013; Prieto and Pérez-Santana, 2014; Carnerud et al., 2018; de Souza et al., 2018; Sanchez-Ruiz and Blanco, 2019; Sánchez-Ruiz et al., 2019; Sanchez-Ruiz et al., 2020; PaipaGaleano et al., 2020) and in terms of employee satisfaction and commitment (García et al., 2013, 2014; Jurburg et al., 2017; Stelson et al., 2017; Alvarado-Ramírez et al., 2018; Paganelli et al., 2018; Sakowski and Marcinkiewicz, 2019; Sanchez-Ruiz and Blanco, 2019; Scharf et al., 2019; Paipa-Galeano et al., 2020; Tortorella et al., 2020; Marin-Garcia and Bonavia, 2021), reports of unsuccessful application or management attempts are recurring (Easton and Jarrell, 1998; Bessant et al., 2001; Hackman and Coutu, 2009; McLean et al., 2017; Rantala et al., 2018; Sunder and Prashar, 2020; Tavana et al., 2021), and also, the effects of these initiatives on long-term benefits and their sustainability remain debated (Jaca et al., 2012; Jurburg et al., 2016; Mendez and Vila-Alonso, 2018; Gutierrez-Gutierrez and Antony, 2020).

In this context there is a need for developing studies and measurements regarding continuous improvement and its interrelationships (Bateman, 2005; Hackman and Coutu, 2009; Bonavia et al., 2015; Sanchez-Ruiz and Blanco, 2019; MarinGarcia et al., 2020; Sanchez-Ruiz et al., 2020; Marin-Garcia and Bonavia, 2021); correctly plan the implementation of these programs, as unsuccessful implementation cause organizations to waste resources, fall short of performance objectives, rework designs, and extend time to market and by considering the right issues and the facilitators and barriers perceived by workers, enable organizations to better understand how to plan for and manage them to achieve the improvement expected, both in terms of economic performance (Hackman and Coutu, 2009; Subramony, 2009) and employee commitment and well-being (Saa Perez et al., 2001; de Koeijer et al., 2014; Mendez and Vila-Alonso, 2018).

The data set provided aims to increase understand how to effectively use this kind of programs to obtain advantages that outweigh their costs, through the responses made by workers and managers to an interview designed by authors, in which four formal participation programs are analyzed: individual suggestions systems, permanent suggestions group systems, ad-hoc groups and semi-autonomous groups. By means the responses and opinions of the interviewees, the data set can be analyzed from different perspectives, such us:

- Perceived benefits of the use of these practices

- Barriers and facilitators

- Differences in perceptions depending on the program implemented

- The relevance of the different contour conditions provided (country, type of company, size of company, etc.)
- Additionally, applying different perspectives, like the AMO perspective (Ability, Motivation, Opportunity) (Bailey, 1993; Marin-Garcia and Martinez Tomas, 2016) or the traditionally constructs identified by Lawler (1986) (training, communication, rewards, empowerment) the dataset can be used in order to identify facilitators and barriers for the improvement of participation programs.

And finally, potential replication studies is also available, in order to researchers can advance, extend, and deepen the processes of the implementation of participation programs for continuous improvement in companies.

\section{METHODS \\ Ethical Statement}

The authors comply with the Scientific Integrity Policy and good research practices of the Universitat Politècnica de València-UPV, dated by $9 / 11 / 12$. This study was reviewed and approved by Ethical Committee of the Universitat Politècnica de ValènciaUPV (CEI_P7_18_06_19).

\section{Participants}

A total of 1,090 employees (managers and workers) were asked about context questions and if they had participated in the following programs to promote Continuous Improvement (CI) in the past 12 months: suggestion boxes, permanent team suggestion systems, short-term team suggestion systems, and self-directed work teams. The interview questionnaire included open-ended questions to obtain data on workers' and managers' perceptions of the CI programs.

The data was obtained along seven academic courses (2008-2009 to 2014-2015) using semi-structured open-ended interviews. In order to get as many responses as possible, we chose to use Purposive snowball sampling procedure (Morse, 2009; Saunders et al., 2009; Emmel, 2013) integrating the data collection in two degrees and a MOOC taught by researchers at the UPV (Valencia, Spain), so that students conducted interviews with workers or supervisors or managers in their closest circle with the only limitation that they had to know the interviewee. Given that the students come from different countries, the sample also contains data from different countries and types of companies, although the answers are in Spanish because the interviewers are Spanish speakers.

These students previously received $40 \mathrm{~h}$ of training and instruction about the interview contents and the way it would be carried out. In this training, the interviewers were introduced in the concepts of relevance and accuracy, in order to ensure to having data for which the estimates are as close to the true values as possible, by minimizing biases.

By prioritizing voluntary participation through purposive snowball sampling, we have lost statistical representativeness. However, this method provides other advantages that we have valued as more important, not only at an economic level but also fundamentally for the data's reliability (Noy, 2008; 
Cassell et al., 2017). The interviewees have been involved in the project through the interviewers and have contributed the data voluntarily and altruistically.

\section{Procedure}

The design of the questions and the collection of data has been carried out in three stages. In the first phase, in line with previous research conducted by our research team in this field (Conci, 2012; Marin-Garcia and Conci, 2013; Juarez-Tarraga et al., 2016), we set out to analyze in-depth the level of implementation of high involvement human resource management practices to promote continuous improvement in companies, through data and perceptions of employees of the companies. As a result of this analysis, the work focused on the four programmes identified, as they have been considered, on the basis of previous research, as the most commonly used (Lawler et al., 2001; MarinGarcia and Bonavia, 2015; Marin-Garcia et al., 2018, 2020). The questionnaire included questions with control variables, commonly used in this type of questionnaire (Cassell et al., 2017), and the original questions that we considered of interest for our research, linked to the use of the selected practices. At this point it is important to highlight the possibilities offered by the open questions included, given that they facilitate the free expression of the opinions and perceptions of the interviewees, in order to elicit responses from respondents so that the researchers' interests do not bias the research results.

In the second phase, the identification and selection of participants was carried out as described in the previous section, with the aim of obtaining as many responses as possible.

And finally, in the third phase, the information is obtained and codified. To ensure data integrity, both the interviewers and the interviewees have carried out their tasks voluntarily. The interviews were conducted face-to-face and recorded when possible (in other cases verbatim copy of responses were written down by interviewers and checked before close the interview), the answers were anonymous, the written consent was obtained from the participants before the interview, and the participants did not receive any monetary compensation.

After conducting the interviews, the interviewers transcribe the data to a web platform to archive information.

In order to avoid errors and biases in the data transcription, the interviewers were previously trained.

The data are provided in both Excel and SPSS formats, and we have also included in this article descriptive tables (data grouping, mean values, etc.) that have been considered relevant to highlight the usefulness of the data and the possibilities of further in-depth analysis, mainly with the qualitative analysis of the data provided in the open-ended questions.

\section{DATA SET DESCRIPTION}

All the variables collected are linked with the implementation of the four formal participation programs that we have selected in our research: individual suggestions systems, permanent suggestions group system, ad-hoc groups and semi-autonomous groups. The questionnaire contains a total of 28 items, which are structured in two groups. The first part's objective is to collect data about the organization and the interviewed, and the next 18 questions are related with the formal participation programs (see Table 1).

Raw data are available on https://zenodo.org/record/ 4607445\#.YFCYN9wo-Co. A descriptive analysis of these data is included in the next tables to highlight the possibility of further analysis.

We think recall bias is not likely because the questions we ask are reasonably objective and refer to four different exposures to easily identifiable CI programs. Although the responses can be affected by respondents' memory failure, this would affect the statistical power and reduce its effect on the relationship between $\mathrm{CI}$ and other variables, which could be higher than the results indicate (Raphael, 1987).

In Table 2, we can see descriptive information related to the closed questions:

Related to the open-ended questions, in order to highlight the possibilities of a further and profound analysis of the data set, using qualitative analysis software, the future investigators can establish the coding and categorization of concepts, and the possible types of relationships/links between them, in order to generate sets of well-related concepts, linked by means of relationship statements, which together can form an integrated conceptual framework that can be used to identify or predict phenomena.

The possibilities offered by the dataset, qualitative analysis and also with mix method (quantitative and qualitative) (Fielding and Fielding, 2011; Cortini, 2014), are important, and we provide below not only the number of words available for analysis, but also the codes, categories and types of relationships that future researchers could apply:

- Numbers of words available for analysis:

(13) V-03-06 Why?: 7,348 words

(15) V-04-10 Positive things you like about this system: 3,205 words

(16) V-04-11 Things that you do not like about this system: 2,098 words

(18) V-04-13 Why?: 9,957 words

(20) V-05-08 Positive things you like about this system: 3,253 words

(21) V-05-09 Things that you do not like about this system: 2,106 words

(23) V-05-11 Why?: 7,735 words

(25) V-06-06 Positive things you like about this system: 4,249 words

(26) V-06-07 Things that you do not like about this system: 3,221 words

(28) V-06-09 Why?: 7,387 words

- Codes and/or categories for qualitative analysis: constraints, weakness, barriers, drawbacks, disadvantages, advantages, facilitators, strengths, and even actions (training, communication, improvement of working conditions, compensation, etc.), among others.

- Relations between codes and/or categories that can be explored: Is associated with; is part of; is cause of; contradicts; is up; is property of; difficult; no name, etc. 
TABLE 1 | Questionnaire.

\begin{tabular}{|c|c|c|c|c|}
\hline Order & Part & Id & Question & Question in English \\
\hline 1 & General & V-01-01 & Año & Year \\
\hline 2 & General & V-01-02 & $\begin{array}{l}\text { Nombre de la localidad/pueblo y país donde } \\
\text { trabaja el encuestado }\end{array}$ & Name of the city/town where the interviewee works \\
\hline 3 & General & V-01-04 & $\begin{array}{l}\text { Actividad económica/Sector: Industrial } \\
\text { (producción); Construcción; Servicio }\end{array}$ & $\begin{array}{l}\text { Sector: } \square \text { Industrial (production) } \square \text { Construction } \\
\square \text { Services }\end{array}$ \\
\hline 4 & General & V-01-05 & $\begin{array}{l}\text { Cantidad de trabajadores en la planta } \\
\text { industrial, oficina, tienda o centro de trabajo } \\
\text { donde trabaja el empleado }\end{array}$ & Number of workers in the plant \\
\hline 5 & General & V-01-06 & $\begin{array}{l}\text { Tipo de empresa: Sólo una planta/oficina; } \\
\text { Varias plantas/oficinas, en un mismo país; } \\
\text { Varias plantas/oficinas, alguna en diferentes } \\
\text { países }\end{array}$ & $\begin{array}{l}\text { Type of company: } \square \text { Only one plant/office } \square \text { Several } \\
\text { plants/offices in the same country } \square \text { Several } \\
\text { plants/offices in different countries }\end{array}$ \\
\hline 6 & General & V-02-01 & género: & V-02-01.- Sex \\
\hline 7 & General & V-02-02 & Edad en años & Age (years) \\
\hline 8 & General & V-02-03 & Años contratado en esta empresa & Years employed in this company \\
\hline 9 & General & V-02-04 & $\begin{array}{l}\text { Nivel de mando: Operario (sin personas a su } \\
\text { cargo); Mando operativo (los subordinados son } \\
\text { operarios); Otros mandos (sus subordinados } \\
\text { son mandos) }\end{array}$ & $\begin{array}{l}\text { Management level: } \square \text { Operator (without subordinates) } \square \\
\text { Operative level (the subordinates are operators) } \square \text { Other } \\
\text { levels (the subordinates are commanders) }\end{array}$ \\
\hline 10 & General & V-02-05 & $\begin{array}{l}\text { Cuántas personas trabajan en su unidad } \\
\text { (OPERARIOS a cargo del mismo mando) }\end{array}$ & $\begin{array}{l}\text { How many people work in your unit (OPERATORS } \\
\text { under the same command) }\end{array}$ \\
\hline 11 & Participation programs & V-03-01 & $\begin{array}{l}\text { ¿existen Buzones de sugerencia en la } \\
\text { empresa? }\end{array}$ & $\begin{array}{l}\text { Systems of individual suggestions (suggestion boxes or } \\
\text { similar). Do they exist in the company? }\end{array}$ \\
\hline 12 & Participation programs & V-03-05 & $\begin{array}{l}\text { Si su empresa no tiene sistemas de } \\
\text { sugerencias tipo buzón de sugerencia o } \\
\text { similares ¿le gustaría a usted que existieran? }\end{array}$ & $\begin{array}{l}\text { If your company does not have any suggestion } \\
\text { systems, would you like them to exist? }\end{array}$ \\
\hline 13 & Participation programs & V-03-06 & ¿Por qué?: & Why? \\
\hline 14 & Participation programs & V.04.01 & $\begin{array}{l}\text { ¿existen grupos de sugerencia permanentes } \\
\text { en la empresa? }\end{array}$ & $\begin{array}{l}\text { Suggestion systems or troubleshooting systems in } \\
\text { PERMANENT teams (quality circles, innovation teams, } \\
\text { Kaizen, Six Sigma). Do they exist in the company? }\end{array}$ \\
\hline 15 & Participation programs & V-04-10 & Cosas positivas que le ve a estos grupos: & Positive things you like about this system: \\
\hline 16 & Participation programs & V-04-11 & Cosas que no le gustan de estos grupos: & Things that you do not like about this system: \\
\hline 17 & Participation programs & V-04-12 & $\begin{array}{l}\text { Si su empresa no tiene sistemas de } \\
\text { sugerencias en grupos permanentes ¿le } \\
\text { gustaría a usted que existieran/participar?: }\end{array}$ & $\begin{array}{l}\text { If your company does not have any suggestion systems } \\
\text { in permanent teams. Would you like them to } \\
\text { exist/would you like to participate?: }\end{array}$ \\
\hline 18 & Participation programs & V-04-13 & ¿Por qué?: & Why? \\
\hline 19 & Participation programs & V-05-01 & ¿existen grupos ad-hoc en la empresa? & $\begin{array}{l}\text { Suggestion systems or troubleshooting systems in } \\
\text { SPORADIC teams (Project teams of short duration,...). } \\
\text { Do they exist in the company? }\end{array}$ \\
\hline 20 & Participation programs & V-05-08 & Cosas positivas que le ve a este sistema & Positive things you like about this system: \\
\hline 21 & Participation programs & V-05-09 & Cosas que no le gustan de estos grupos & Things that you do not like about this system: \\
\hline 22 & Participation programs & V-05-10 & $\begin{array}{l}\text { Si su empresa no tiene grupos ad-hoc ¿le } \\
\text { gustaría a usted que existieran/participar?: }\end{array}$ & $\begin{array}{l}\text { If your company does not have any suggestion systems } \\
\text { in sporadic teams. Would you like them to exist/would } \\
\text { you like to participate?: }\end{array}$ \\
\hline 23 & Participation programs & V-05-11 & ¿Por qué?: & Why? \\
\hline 24 & Participation programs & V-06-01 & $\begin{array}{l}\text { ¿existen GRUPOS DE TRABAJO } \\
\text { SEMIAUTÓNOMO en la empresa? }\end{array}$ & $\begin{array}{l}\text { Teamwork or semi-autonomous teams. Do they exist in } \\
\text { the company? }\end{array}$ \\
\hline 25 & Participation programs & V-06-06 & Cosas positivas que le ve a estos grupos: & Positive things you like about this system: \\
\hline 26 & Participation programs & V-06-07 & Cosas que no le gustan de Estos grupos: & Things that you do not like about this system \\
\hline 27 & Participation programs & V-06-08 & $\begin{array}{l}\text { (Si su empresa no tiene GRUPOS DE } \\
\text { TRABAJO SEMIAUTÓNOMO) ¿le gustaría a } \\
\text { usted que existieran/participar?: }\end{array}$ & $\begin{array}{l}\text { If your company does not have any teamwork or } \\
\text { semi-autonomous teams, would you like them to } \\
\text { exist/would you like to participate?: }\end{array}$ \\
\hline 28 & Participation programs & V-06-09 & ¿Por qué?: & Why?: \\
\hline
\end{tabular}


TABLE 2 | Description ended questions.

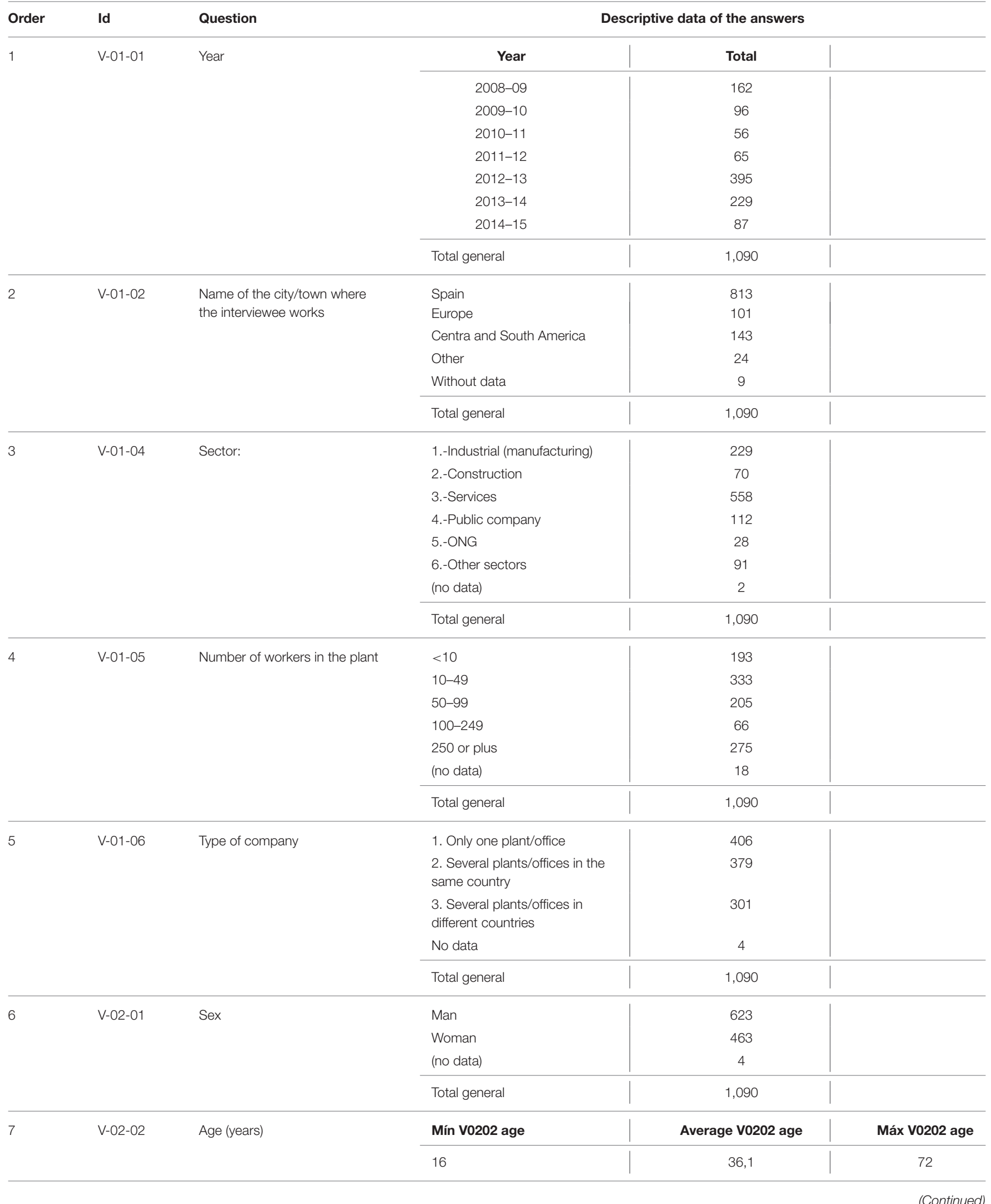


TABLE 2 | Continued

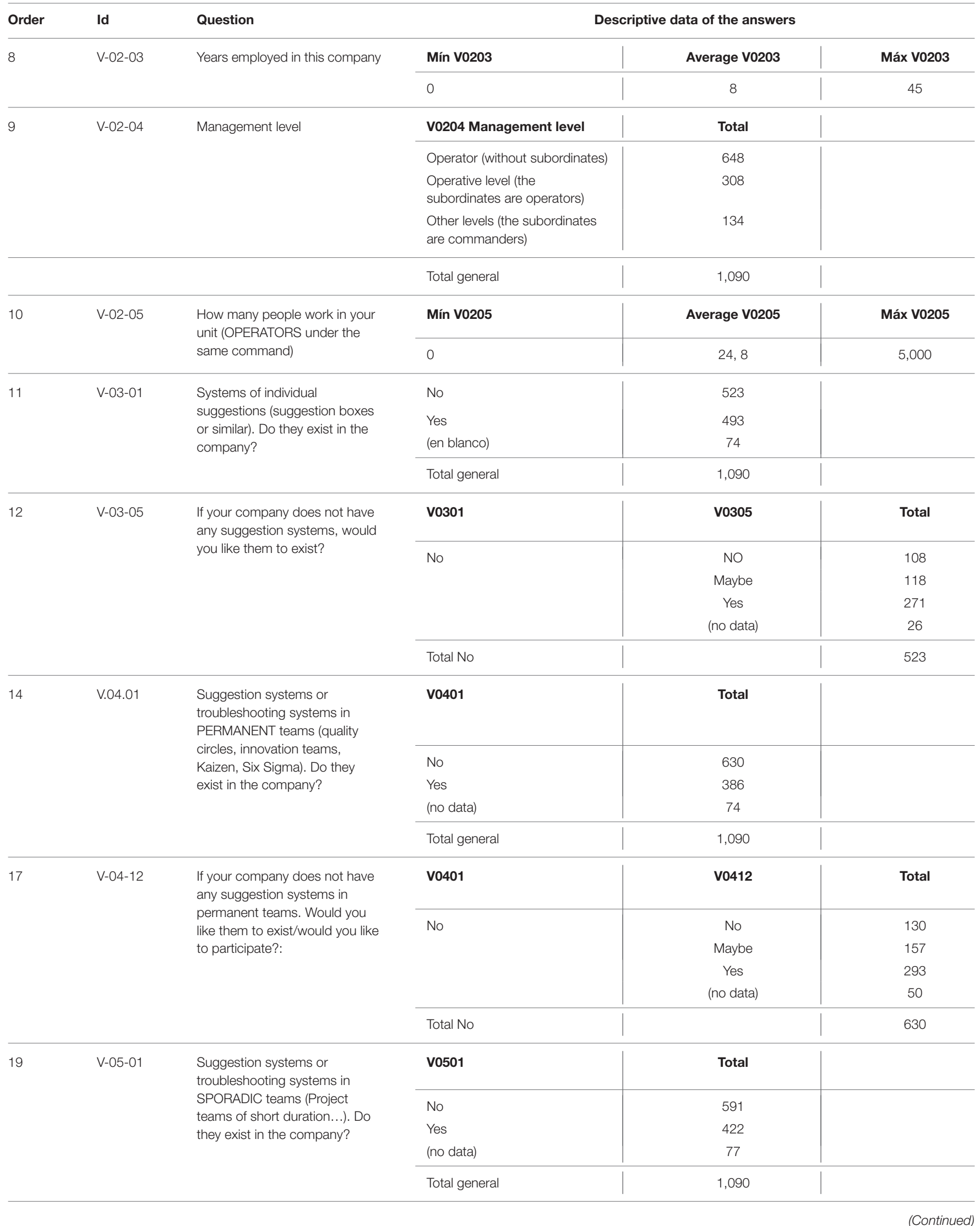


TABLE 2 | Continued

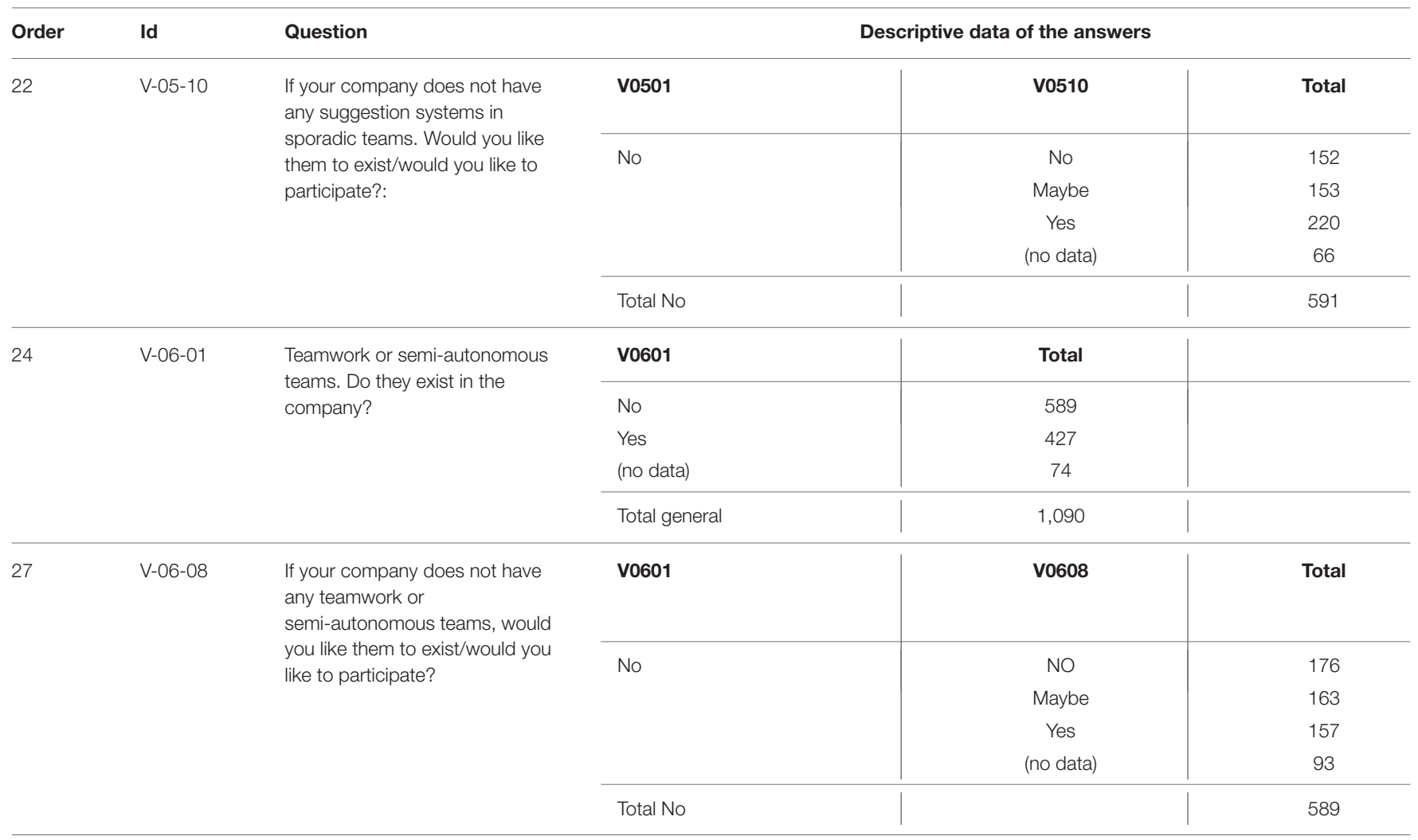

\section{SUGGESTIONS OF FUTURE AVENUES OF RESEARCH USING THIS DATA SET}

The data set provides information about the use of participative programs in companies and the opinions and perceptions about facilitators and barriers identified by workers and managers during these programs' implementation.

Given that the questionnaire used to obtain the data set poses some open-ended questions, in contrast to the results that can be obtained using closed questionnaires, the data set contains evoked responses that allow to obtain conclusions not predetermined by the researcher but by the interviewee (Atieno, 2009; Robinson, 2014).

The data may be of interest to researchers as well as human resources managers. Researchers on human resources and continuous improvement programs can use this data set to analyze the implementation of formal participative programs (individual suggestions systems; permanent suggestions group system; short-term improvement groups; semi-autonomous groups) and understand and investigate the team phenomena and their effectiveness. The qualitative and quantitative data obtained through the questions formulated provides a wide range of valuable information to analyze aspects as:

- Perceived benefits of the use of these practices

- Barriers and facilitators

- Implications for working conditions and employee well-being
- Actions implemented related with communication, training, compensation, participation, etc...

- Relations with the four programs analyzed and contour conditions provided (country, type of company, size of company, sector, etc.)

- Differences in perceptions depending on the program implemented

- The relevance of the different contour conditions provided (country, type of company, size of company, etc.)

- Additionally, applying different perspectives, like the AMO perspective (Ability, Motivation, Opportunity) (Bailey, 1993; Marin-Garcia and Martinez Tomas, 2016) or the traditionally constructs identified by Lawler (1986) (training, communication, rewards, empowerment) the dataset can be used in order to identify facilitators and barriers for the improvement of participation programs

Human Resource Managers interested in using these continuous improvement programs can use this data as a benchmark to know the perceptions and expectations of workers and managers.

Our data were obtained face to face in individual interviews carried out over several years, and potential replication studies are also available. Researchers can advance, extend, and deepen the processes of implementing participation programs in companies.

The complexity of the production and service provision environment present critical and new challenges for researchers 
and managers. Review how the approaches remain valid in companies is essential to learn if these programs (individuals and in team) are to succeed or even if synergies can be achieved (Kozlowski and Bell, 2013).

Data shared in this data article will open up doors for new research collaborations. The authors welcome future collaborations with other researchers and welcome the opportunity to contribute to a similar survey design in other countries.

\section{DATA AVAILABILITY STATEMENT}

The datasets presented in this study can be found online at: https://zenodo.org/record/4607445\#.YFCYN9wo-Co.

\section{REFERENCES}

Alvarado-Ramírez, K. M., Pumisacho-Álvaro, V. H., Miguel-Davila, J. Á., and Suárez Barraza, M. F. (2018). Kaizen, a continuous improvement practice in organizations: a comparative study in companies from Mexico and Ecuador. TQM J. 30, 255-268. doi: 10.1108/TQM-07-2017-0085

Appelbaum, E., Bailey, T., Berg, P., Kalleberg, A. L., and Cornell, N. Y. (2000). Manufacturing advantage : why high- perlormance work systems pay oft by. Acad. Manag. Rev. 26, 459-462. doi: 10.2307/259189

Atieno, O. P. (2009). An analysis of the strengths and limitation of qualitative and quantitative research paradigms. Probl. Educ. 21st Century 13, 13-18.

Bailey, T. (1993). Organizational innovation in the apparel industry. Ind. Relat. A J. Econ. Soc. 32, 30-48. doi: 10.1111/j.1468-232X.1993.tb01017.x

Bateman, N. (2005). Sustainability: the elusive element of process improvement. Int. J. Oper. Prod. Manag. 25, 261-276. doi: 10.1108/01443570510581862

Berger, A. (1997). Continuous improvement and kaizen: standardization and organizational designs. Integr. Manuf. Syst. 8, 110-117. doi: 10.1108/09576069710165792

Bessant, J., Caffyn, S., and Gallagher, M. (2001). An evolutionary model of continuous improvement behaviour. Technovation 21, 67-77. doi: 10.1016/S0166-4972(00)00023-7

Bhuiyan, N., and Baghel, A. (2005). An overview of continuous improvement: from the past to the present. Manage. Decision 43, 761-771. doi: 10.1108/00251740510597761

Bonavia, T., Molina, J. G., and Puchol, A. (2015). Structural validity of a questionnaire to measure effective behaviors in work teams. Ann. Psychol. 31, 667-676. doi: 10.6018/analesps.31.2.184041

Carnerud, D., Jaca, C., and Bäckström, I. (2018). Kaizen and continuous improvement - trends and patterns over 30 years. TQM J. 30, 371-390. doi: 10.1108/TQM-03-2018-0037

Cassell, C., Cunliffe, A., and Grandy, G. (2017). "The SAGE handbook of qualitative business and management research methods: methods and challenges," in Qualitative Business and Management Research Methods: Methods and Challenges, ed Ltd. SP (London), 624. SAGE Publications.

Chalmers, D. (2013). Social innovation: an exploration of the barriers faced by innovating organizations in the social economy. Local Econ. 28, 17-34. doi: $10.1177 / 0269094212463677$

Conci, G. (2012). Perceived results obtained by companies associated to the use of high involvement work practices (HIWP). Work Pap. Oper. Manag. 3, 1-15. doi: 10.4995/wpom.v3i1.1065

Cortini, M. (2014). Mix-method research in applied psychology. Mediterr. J. Soc. Sci. 5, 1900-1905. doi: 10.5901/mjss.2014.v5n23p1900

de Koeijer, R. J., Paauwe, J., and Huijsman, R. (2014). Toward a conceptual framework for exploring multilevel relationships between Lean Management and Six Sigma, enabling HRM, strategic climate and outcomes in healthcare. Int. J. Hum. Resour. Manag. 25, 2911-2925. doi: 10.1080/09585192.2014.953974

de Souza, I. G., Lacerda, D. P., Camargo, L. F. R., Dresch, A., and Piran, F. S. (2018). Do the improvement programs really matter? An

\section{ETHICS STATEMENT}

The authors comply with the Scientific Integrity Policy and good research practices of the Universitat Politècnica de València-UPV, dated by $9 / 11 / 12$. This study was reviewed and approved by Ethical Committee of the Universitat Politècnica de València-UPV (CEI_P7_18_06_19). Written informed consent was obtained from the participants before the interview.

\section{AUTHOR CONTRIBUTIONS}

All authors listed have made a substantial, direct and intellectual contribution to the work, and approved it for publication.

analysis using data envelopment analysis. BRQ Bus. Res. Q. 21, 225-237. doi: 10.1016/j.brq.2018.08.002

Easton, G. S., and Jarrell, S. L. (1998). The effects of total quality management on corporate performance: an empirical investigation. J. Bus. 71, 253-307. doi: $10.1086 / 209744$

Emmel, N. (2013). Sampling and Choosing Cases in Qualitative Research: A Realist Approach. London: SAGE Publications Ltd.

EUROFOUND (2016). Sixth European Working Conditions Survey: 2015. Available online at: https://www.eurofound.europa.eu/surveys/europeanworking-conditions-surveys/sixth-european-working-conditions-survey2015 (accessed August 24, 2021).

EUROFOUND (2020). Only One-Fifth of European Companies Find Secret to Combining Optimal Workplace Wellbeing and Business Performance. p. 1. Available online at: https:/www.eurofound.europa.eu/news/news-articles/ one-fifth-of-european-companies-combine-optimal-workplace-wellbeingand-business-performance (accessed August 24, 2021).

Fielding, N., and Fielding, J. (2011). Linking data. Qual. Res. Methods 4:96. doi: $10.4135 / 9781412984775$

García, J. L., Maldonado, A. A., Alvarado, A., and Rivera, D. G. (2014). Human critical success factors for kaizen and its impacts in industrial performance. Int. J. Adv. Manuf. Technol. 70, 2187-2198. doi: 10.1007/s00170-0135445-4

García, J. L., Rivera, D. G., and Iniesta, A. A. (2013). Critical success factors for Kaizen implementation in manufacturing industries in Mexico. Int. J. Adv. Manuf. Technol. 68, 537-545. doi: 10.1007/s00170-013-4750-2

García-Lorenzo, A., and Prado, J. (2003). Employee participation systems in Spain. Past, present and future. Total Qual. Manag. Bus Excell. 14, 15-24. doi: 10.1080/14783360309704

Garcia-Sabater, J. J., and Marin-Garcia, J. A. (2009). Enablers and inhibitors for sustainability of continuous improvement: a study in the automotive industry suppliers in the Valencia Region. Intang. Cap. 5, 183-209. doi: 10.3926/ic.2009.v5n2.p183-209

Gutierrez-Gutierrez, L., and Antony, J. (2020). Continuous improvement initiatives for dynamic capabilities development: a systematic literature review. Int. J. Lean Six Sigma. 11, 125-149. doi: 10.1108/IJLSS-07-20180071

Hackman, J. R., and Coutu, D. (2009). Why teams don't work. Harvard Bus. Rev. 87, 98-130. doi: 10.1007/0-306-47144-2_12

Jaca, C., Viles, E., Mateo, R., and Santos, J. (2012). Components of sustainable improvement systems: theory and practice. TQM J. 24, 142-154. doi: 10.1108/17542731211215080

Jaca-Garcia, M. C., and Santos-Garcia, J. (2009). Continuous improvement in organizations. Analysis of its implementation in 30 companies. DYNA 84, 133-140. doi: 10.6036/1964

Juarez-Tarraga, A., Marin-Garcia, J. A., and Santandreu-Mascarell, C. (2016). High involvement work programs (HIWP) measurement model validation and its capacity to predict perceived performance. Intang. Cap. 12, 1308-1400. doi: $10.3926 /$ ic. 837 
Jurburg, D., Viles, E., Tanco, M., and Mateo, R. (2017). What motivates employees to participate in continuous improvement activities? Total Quality Manage. Bus. Excellence 28, 1469-1488. doi: 10.1080/14783363.2016.1 150170

Jurburg, D., Viles, E., Tanco, M., Mateo, R., and Lleó, A. (2016). Measure to succeed: how to improve employee participation in continuous improvement. J. Ind. Eng. Manag. 9, 1059-1077. doi: 10.3926/jiem.2074

Kozlowski, S., and Bell, B. (2013). Work groups and teams in organizations: review update. Handb. Psychol. 12, 412-469. doi: 10.1002/0471264385. wei1214

Lawler, I. I. I. E. E. (1986). High-Involvement Management. Participative Strategies for Improving Organizational Performance. San Francisco, CA: Jossey-Bass Inc., Publishers.

Lawler, I. I. I. E. E., Mohrman, S. A., and Benson, G. (2001). Organizing for High Performance: Employee Involvement, TQM, Reengineering, and Knowledge Management in the Fortune 1000. The CEO report. Jossey-Bass. 267p. San Francisco.

Lee, F. H., Lee, T. Z., and $\mathrm{Wu}, \mathrm{W}$. Y. (2010). The relationship between human resource management practices, business strategy and firm performance: evidence from steel industry in Taiwan. Int. J. Hum. Resour. Manag. 21, 1351-1372. doi: 10.1080/09585192.2010.4 88428

Lillrank, P., Shani, A. B., and Lindberg, P. (2001). Continuous improvement: exploring alternative organizational designs. Total Qual. Manag. 12, 41-55. doi: 10.1080/09544120020010084

Marin-Garcia, J. A. (2013). What do we know about the relationship between High Involvement Work Practices and Performance? Work Pap. Oper. Manag. 4, 1-15. doi: 10.4995/wpom.v4i2.1552

Marin-Garcia, J. A., Bonavia Martin, T., and Miralles, C. (2008). The use of employee participation in the USA and Spanish companies. Int. J. Manag. Sci. Eng. Manag. 3, 71-80. doi: 10.1080/17509653.2008.10671037

Marin-Garcia, J. A., and Bonavia, T. (2015). Relationship between employee involvement and lean manufacturing and its effect on performance in a rigid continuous process industry. Int. J. Prod. Res. 53, 3260-3275. doi: 10.1080/00207543.2014.975852

Marin-Garcia, J. A., and Bonavia, T. (2021). Empowerment and employee wellbeing: a mediation analysis study. Int. J. Environ. Res. Public Health 18, 1-22. doi: 10.3390/ijerph18115822

Marin-Garcia, J. A., Bonavia, T., and Losilla, J. M. (2020). Changes in the association between european workers' employment conditions and employee well-being in 2005, 2010 and 2015. Int. J. Environ. Res. Public Health 17, 1-22. doi: 10.3390/ijerph17031048

Marin-Garcia, J. A., and Conci, G. (2013). Validación de un cuestionario para medir el grado de uso de las prácticas de alta implicación de los trabajadores. Intang. Cap. 9, 854-882. doi: 10.3926/ic.417

Marin-Garcia, J. A., Garcia-Sabater, J. J., and Bautista Poveda, Y. (2012). Etapas en la evolución de la mejora continua. ¿Como viven las empresas este proceso? Estudio de un caso. Econ. Ind. 384:153-163.

Marin-Garcia, J. A., Juarez-Tarraga, A., and Santandreu-Mascarell, C. (2018). Kaizen philosophy: the keys of the permanent suggestion systems analyzed from the workers' perspective. TQM J. 30, 296-320. doi: 10.1108/TQM-12-2017-0176

Marin-Garcia, J. A., and Martinez Tomas, J. (2016). Deconstructing AMO framework: a systematic review. Intang. Cap. 12, 1040-1087. doi: 10.3926/ic.838

Mathieu, J., Maynard, M. T., Rapp, T., and Gilson, L. (2008). Team effectiveness 1997-2007: a review of recent advancements and a glimpse into the future. J. Manage. 34, 410-476. doi: 10.1177/0149206308 316061

McLean, R. S., Antony, J., and Dahlgaard, J. J. (2017). Failure of Continuous Improvement initiatives in manufacturing environments: a systematic review of the evidence. Total Qual. Manag. Bus. Excell. 28, 219-237. doi: 10.1080/14783363.2015.1063414

Mendez, J., and Vila-Alonso, M. (2018). Three-dimensional sustainability of Kaizen. TQM J. 30, 391-408. doi: 10.1108/TQM-12-20 17-0179

Morse, J. M. (2009). "Sampling for mixed method designs," in Mixed Method Design (Routledge).
Noy, C. (2008). Sampling knowledge: the hermeneutics of snowball sampling in qualitative research. Int. J. Soc. Res. Methodol. 11, 327-344. doi: 10.1080/13645570701401305

Paganelli, M., Madeo, E., Nabeel, I., Lecca, L. I., Pilia, I., Pili, S., et al. (2018). Education and training in global occupational health and safety: a perspective on new pathways to sustainable development. Ann. Glob. Heal. 84, 538-540. doi: 10.29024/aogh.2309

Paipa-Galeano, L., Bernal-Torres, C. A., Agudelo-Otalora, L. M., Jarrah-Nezhad, Y., and González-Blanco, H. A. (2020). Key lessons to sustain continuous improvement: a case study of four companies. J. Ind. Eng. Manag. 13, 195-211. doi: 10.3926/jiem.2973

Prieto, I. M., and Pérez-Santana, M. P. (2014). Managing innovative work behavior: the role of human resource practices. Pers. Rev. 43, 184-208. doi: 10.1108/PR-11-2012-0199

Rantala, T., Pekkola, S., Rantanen, H., and Hannula, M. (2018). Evolution of obstacles restraining productivity improvement. Int. J. Prod. Qual. Manage. 25, 64-89. doi: 10.1504/IJPQM.2018.094293

Raphael, K. (1987). Recall bias: a proposal for assessment and control. Int. J. Epidemiol. 16, 167-170. doi: 10.1093/ije/16. 2.167

Robinson, O. C. (2014). Sampling in interview-based qualitative research: a theoretical and practical guide a theoretical and practical guide. Qual. Res. Psychol. 11, 25-41. doi: 10.1080/14780887.2013.8 01543

Saa Perez, P., Déniz Déniz M. de la, C., and Univ.Las Palmas de Gran Canaria, E. (2001). La capacidad de respuesta corporativa hacia los empleados mediante la gestion de alto compromiso. Rev. Econ. Empres. $15,69-86$.

Sakowski, P., and Marcinkiewicz, A. (2019). Health promotion and prevention in occupational health systems in Europe. Int. J. Occup. Med. Environ. Health 32, 353-361. doi: 10.13075/ijomeh.1896.01384

Sanchez-Ruiz, L., and Blanco, B. (2019). Survey dataset on reasons why companies decide to implement continuous improvement. Data Br. 26:104523. doi: 10.1016/j.dib.2019.104523

Sánchez-Ruiz, L., Blanco, B., and Gómez-López, R. (2019). Continuous improvement enablers: defining a new construct. J. Ind. Eng. Manag. 12, 51-69. doi: 10.3926/jiem.2743

Sanchez-Ruiz, L., Blanco, B., Marin-Garcia, J. A., and Diez-Busto, E. (2020). Scoping review of kaizen and green practices: state of the art and future directions. Int. J. Environ. Res. Public Health 17, 1-19. doi: $10.3390 /$ ijerph 17218258

Sandengen, O. C., Estensen, L. A., Rodseth, H., and Schjolberg, P. (2016). High performance manufacturing - an innovative contribution towards industry 4.0. Proc. 6th Int. Work Adv. Manuf. Autom. 24, 14-20. doi: 10.2991/iwama-16.2016.3

Saunders, M., Lewis, P., and Thornhill, A. (2009). Research Methods for Business Students. New York: Prentice Hall.

Scharf, J., Vu-Eickmann, P., Li, J., Müller, A., Wilm, S., Angerer, P., et al. (2019). Desired improvements of working conditions among medical assistants in Germany: a cross-sectional study. J. Occup. Med. Toxicol. 14, 1-11. doi: 10.1186/s12995-019-0237-x

Stelson, P., Hille, J., Eseonu, C., and Doolen, T. (2017). What drives continuous improvement project success in healthcare? Int. J. Health Care Qual. Assur. 30, 43-57. doi: 10.1108/IJHCQA-03-201 6-0035

Subramony, M. (2009). A meta-analytic investigation of the relationship between HRM bundles and firm performance. Hum. Resour. Manage. 48, 745-768. doi: 10.1002/hrm.20315

Sunder, M. V., and Prashar, A. (2020). Empirical examination of critical failure factors of continuous improvement deployments: stage-wise results and a contingency theory perspective. Int. J. Prod. Res. 58, 4894-4915. doi: 10.1080/00207543.2020.17 27044

Tavana, M., Shaabani, A., and Valaei, N. (2021). An integrated fuzzy framework for analyzing barriers to the implementation of continuous improvement in manufacturing. Int. J. Qual. Reliab. Manag. 38, 116-146. doi: 10.1108/IJQRM-06-2019-0196 
Terziovski, M., and Sohal, A. S. (2000). The adoption of continuous improvement and innovation strategies in Australian manufacturing firms. Technovation 20, 539-550. doi: 10.1016/S0166-4972(99)00173-X

Tortorella, G., van Dun, D. H., and de Almeida, A. G. (2020). Leadership behaviors during lean healthcare implementation: a review and longitudinal study. $J$. Manuf. Technol. Manag. 31, 193-215. doi: 10.1108/JMTM-02-2019-0070

Van Aken, E. M., Farris, J. A., Glover, W. J., and Letens, G. (2010). A framework for designing, managing, and improving Kaizen event programs. Int. J. Product Perform. Manag. 59, 641-667. doi: 10.1108/17410401011075648

Van Dijk, C., and Van Den Ende, J. (2002). Suggestion systems: transferring employee creativity into practicable ideas. R. D. Manag. 32, 387-395. doi: 10.1111/1467-9310.00270

Vinodh, S., Antony, J., Agrawal, R., and Douglas, J. A. (2021). Integration of continuous improvement strategies with industry 4.0: a systematic review and agenda for further research. TQM J. 33, 441-472. doi: 10.1108/TQM-07-2020-0157

Wood, A. (2003). Managing employees' ideas from where do ideas come? J. Qual. Particip. 26:22.
Conflict of Interest: The authors declare that the research was conducted in the absence of any commercial or financial relationships that could be construed as a potential conflict of interest.

Publisher's Note: All claims expressed in this article are solely those of the authors and do not necessarily represent those of their affiliated organizations, or those of the publisher, the editors and the reviewers. Any product that may be evaluated in this article, or claim that may be made by its manufacturer, is not guaranteed or endorsed by the publisher.

Copyright (C) 2021 Juarez-Tarraga, Santandreu-Mascarell and Marin-Garcia. This is an open-access article distributed under the terms of the Creative Commons Attribution License (CC BY). The use, distribution or reproduction in other forums is permitted, provided the original author(s) and the copyright owner(s) are credited and that the original publication in this journal is cited, in accordance with accepted academic practice. No use, distribution or reproduction is permitted which does not comply with these terms. 